\title{
The value of monitoring wildlife roadkill
}

\section{Amy L. W. Schwartz ${ }^{1}$ (D) $\cdot$ Fraser M. Shilling $^{2}$ (D) Sarah E. Perkins $^{1}$ (D)}

Received: 22 November 2018 / Revised: 20 December 2019 / Accepted: 30 December 2019 / Published online: 15 January 2020

(C) The Author(s) 2020

\begin{abstract}
The number of wildlife-vehicle collisions has an obvious value in estimating the direct effects of roads on wildlife, i.e. mortality due to vehicle collisions. Given the nature of the data-species identification and location-there is, however, much wider ecological knowledge that can be gained by monitoring wildlife roadkill. Here, we review the added value and opportunities provided by these data, through a series of case studies where such data have been instrumental in contributing to the advancement of knowledge in species distributions, population dynamics, and animal behaviour, as well as informing us about health of the species and of the environment. We propose that consistently, systematically, and extensively monitoring roadkill facilitates five critical areas of ecological study: (1) monitoring of roadkill numbers, (2) monitoring of population trends, (3) mapping of native and invasive species distributions, (4) animal behaviour, and (5) monitoring of contaminants and disease. The collection of such data also offers a valuable opportunity for members of the public to be directly involved in scientific data collection and research (citizen science). Through continuing to monitor wildlife roadkill, we can expand our knowledge across a wide range of ecological research areas, as well as facilitating investigations that aim to reduce both the direct and indirect effects of roads on wildlife populations.
\end{abstract}

Keywords Wildlife-vehicle conflict · Citizen science $\cdot$ Roads $\cdot$ Road ecology $\cdot$ Invasion ecology $\cdot$ Animal behaviour $\cdot$ Sentinel animals

\section{'Road ecology'—an emerging field}

Major roads split the Earth's terrestrial surface into $\sim 600,000$ patches, of which more than half are $<1 \mathrm{~km}^{2}$ in area, and only $7 \%$ are larger than $100 \mathrm{~km}^{2}$ (Ibisch et al. 2016). Unsurprisingly, wildlife-vehicle collisions are subsequently numerous. Globally, second to legal harvesting, roads are the largest source of anthropogenic mortality for many vertebrates (Hill et al. 2019), with more than a million vertebrates estimated to be killed on roads in the USA per day (Erickson et al. 2005; Loss et al. 2014). Wildlife-vehicle collisions, and the related ecological effects of roads on wildlife, for example the

This article is part of the Topical Collection on Road Ecology

Guest Editor: Marcello D’Amico

Amy L. W. Schwartz

WilliamsSchwartzAL@Cardiff.ac.uk

1 Cardiff School of Biosciences, The Sir Martin Evans Building, Museum Avenue, Cardiff CF10 3AX, UK

2 Road Ecology Center, Department of Environmental Science and Policy, University of California, Davis, CA 95616, USA 'barrier effect'-linear infrastructure reducing animal movements (Forman and Alexander 1998) - have led to the field of 'road ecology', a term first mentioned in the literature 20 years ago (Forman 1998). Since that time, the field has burgeoned, with 'road ecology' peer-reviewed papers on Web of Science increasing dramatically (Fig. 1), and organisations appearing that are dedicated to studying the field, for example the Road Ecology Center at UC Davis, CA (https://roadecology. ucdavis.edu/frontpage), as well as 'citizen science' projects worldwide that collate roadkill observations submitted by members of the public to collect data on road impacts on wildlife (http://globalroadkill.net/) (Shilling et al. 2015). It is expected that at least 25 million kilometres of new roads will be built globally by 2050 , a $60 \%$ increase in road lengths since 2010 (Laurance et al. 2014), so wildlife-vehicle collisions are expected to increase with time (mammal-vehicle collisions have already been shown to have increased significantly since the 1970s; Hill et al. 2019), and with that we expect this discipline to continue to expand too.

In this review, we first provide context to the importance of collecting and collating data of wildlife-vehicle collisions by providing a brief overview of how the collection of such data provides an essential framework for understanding and 


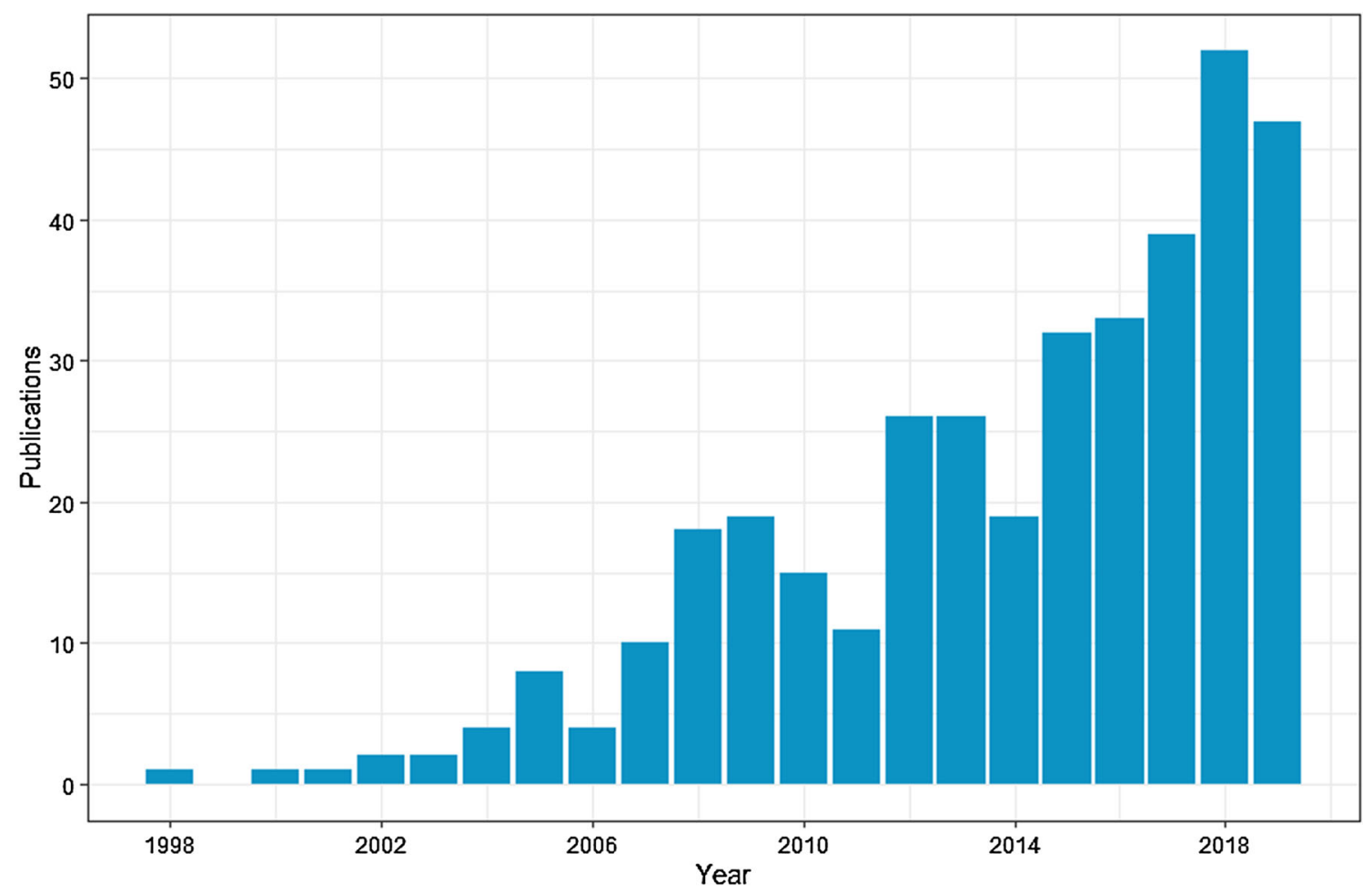

Fig. 1 ISI peer-reviewed publications with 'road ecology' as a topic on Web of Science from 1998 to 2019

quantifying the 'direct' effects of roads on wildlife, i.e. wildlife mortality associated with roads. Reviews exist in the field of road ecology as a whole (Forman and Alexander 1998; Coffin 2007), the use of citizen science in monitoring wildlife roadkill (Shilling et al. 2015; Vercayie and Herremans 2015), and the use and effectiveness of mitigation strategies (Grilo et al. 2010; Rytwinski et al. 2016). Here, we add to this rich literature by focusing on our second aim to describe how the growing systems for collecting wildlife-vehicle collision data also provide rich datasets of ecological data. These new and growing datasets can also inadvertently and sometimes opportunistically provide additional ecological insights, which are the focus of this review. Specifically, we describe how this opportunistic data collection may divulge information on population trends and species distributions, non-native species invasions, and revealing novel animal behaviour. In addition, roadkill carcasses can be used as 'sentinels' for monitoring of environmental contaminants and diseases. Finally, the collection of roadkill data can offer a valuable opportunity for members of the public to get directly involved in scientific data collection and research (citizen science), and we outline ways in which 'citizen scientists' have been instrumental in contributing to roadkill data collection.

\section{Monitoring wildlife-vehicle collision numbers}

The first published count of wildlife-vehicle collisions took place in 1935, in which an individual observer recorded 940 avian mortalities over 4000 miles of road (Barnes 1936). The first citizen science project to quantify wildlife mortality on roads in the UK, however, was organised by the British Trust for Ornithology during 1960-61 (Hodson and Snow 1965). By extrapolating the number of casualties across a given length of road, the annual number of roadkill birds was calculated as approximately 2.5 million. It is important to note, however, that when this study occurred in the 1960s, the UK's roads supported fewer than 8 million vehicles compared with the current-day 38 million (Department for Transport 2018). Present day national roadkill surveys engage citizens across the world (Shilling et al. 2015), with millions of vertebrates estimated to be killed on the roads yearly (Fig. 2). Worldwide, the direct effects of vehicles on population numbers are substantial, for example estimates amount to 340 million birds killed on the roads annually in the USA (Loss et al. 2014) and 13.8 million birds annually in Canada (Bishop and Brogan 2013). Indeed, globally where annual estimates have been calculated, there is not a country that does not have a wildlife-vehicle collision count that is estimated to be in the millions (Fig. 2). Estimating the total number of animals killed on roads, and population impacts from this source of mortality is important in its own right, but as important is the use of wildlife-vehicle collision data to understand other aspects of ecology. Wildlife-vehicle collision data number in the millions and even with limited geographical and taxonomic estimates, in excess of 400 million vertebrate records per year, could be generated using roadkill data (Fig. 2). It is clear that the 


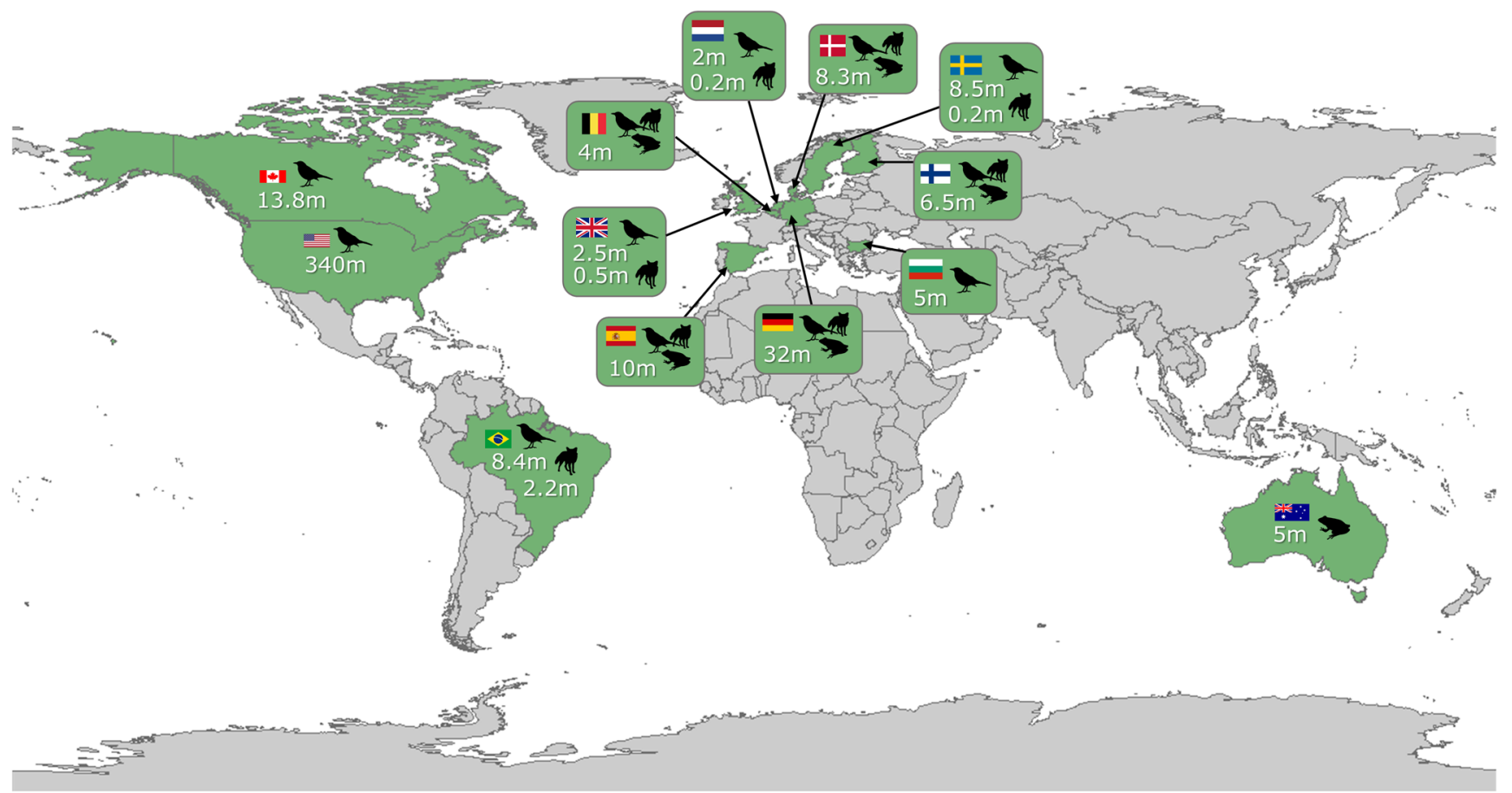

Fig. 2 Available country-level estimates of vertebrate wildlife-vehicle collisions by major taxa (birds, mammals, and amphibians) in millions per year. No annual estimates were found for countries in grey. Data collated from Bishop and Brogan (2013), González-Suárez et al.
(2018), Harris et al. (1992), Hodson and Snow (1965), Langbein (2007), Loss et al. (2014), Seiler and Helldin (2006), and Wembridge et al. (2016)

practical reasons, such as implementation of conservation efforts and management of invasive species (Caley et al. 2015; Guisan et al. 2013). Distribution data for species that are elusive (e.g. nocturnal) or in low densities can be difficult to collect (Kindberg et al. 2009), and such data have traditionally been collected through targeted surveys (e.g. Newman et al. 2003), which may only cover a given area, or time frame. Such surveys are inherently high-cost (Jones 2011). Wildlife-vehicle collision data, however, offers consistent and continuous insight beyond dedicated surveys, due to high geographical coverage and relatively low cost (Shilling et al. 2015).

The presence of a carcass offers incontrovertible evidence of the presence of a given species, leading to the discovery of populations in previously unknown locations. Roadkill monitoring has led to rediscovery of the Indo-Chinese rat snake (Ptyas korros) in Borneo from an incidental roadkill encounter; the first time the species had been recorded in the country for over 100 years (Auliya 2002). Such a contribution to species' distribution data is particularly valuable for species that are difficult to monitor, such as a recovering species, one that is range-expanding and/or nocturnal animals (Calenge et al. 2015; see case study below). The nine-banded armadillo (Dasypus novemcinctus), for example, is an elusive species whose range expansion in the Southern United States is being tracked via roadkill carcasses (Hofmann 2005). In Wales, the first pine marten (Martes martes) in the country since the inherent interest and for knowledge gain, as well as for 
1970s was discovered dead on the road in 2012 (Vincent Wildlife Trust 2012). Prior to this, efforts to determine whether pine marten was still present in Wales had relied solely on the presence of scat (Vincent Wildlife Trust 2012). Similarly, roadkill data have been used to monitor the recovery of the polecat (Mustela putorius) in the UK; over half of all records were road casualties (Croose 2016; see case study below).

New species have been described through monitoring roadkill - a decomposing roadkill bird was collected in the Nechisar National Park, Ethiopia, and on return to the Natural History Museum, London, was confirmed as a new species to science, the Nechisar nightjar (Caprimulgus solala) (Safford et al. 1995). Roadkill can also provide information on the potential of some species to appear well outside their normal range (vagrancy). There are occasions of extremely rare vagrant birds being discovered dead on the road following a vehicle collision. One such example was a common nighthawk (Chordeiles minor) found dead on a road on $\mathrm{St}$ Mary's, Isles of Scilly in 2008, only the 21st record for Britain and Ireland (Hudson and the Rarities Committee 2009). Additionally, the first record of golden nightjar (Caprimulgus eximius) for the Western Palearctic region occurred in 2015 on a road in Morocco after being struck by the observers' car (Dyczkowski 2016).

It is, however, important to state that, as in all ecological surveys, absence of evidence is not evidence of absence. Animals may not be observed as roadkill for a variety of reasons; firstly, they may simply avoid the road completely — species categorised as road 'avoiders' face lower mortality than other species (Jacobson et al. 2016). Secondly, certain species may cross roads safely throughout their distribution, or in places where that is possible, for example via 'green bridges'. Thirdly, the lack of observed roadkill of a given species could be due to previous mass mortality events due to extensive wildlife-vehicle collisions (Ascensão et al. 2019); i.e. a population has already become locally extinct due to traffic pressure. Finally, the persistence of carcasses on the road and so the opportunity to be observed can differ due to a variety of factors such as traffic flow, animal taxon, size (Barrientos et al. 2018), and scavenging rates of the carcass (Schwartz et al. 2018; Barrientos et al. 2018).

\section{Case study - monitoring polecat spread and recovery through roadkill observations}

Although a formerly very widespread species, the polecat in the UK was persecuted almost to extinction in the 1800s and was confined to a stronghold in Mid Wales (Costa et al. 2013). Following the cessation of widespread persecution in the second half of the twentieth century, the population was recovered, recolonising most of Wales and much of central England, with range expansion occurring in South West England and East Anglia (Croose 2016). As a fairly shy and nocturnal species, they can be difficult to monitor, and monitoring efforts can be further complicated by the presence of feral ferrets (Mustela putorius furo), certain morphs of which can be very difficult to tell apart from a 'true' polecat, with which they hybridise (Davison et al. 1999). Members of the public (citizen scientists) collect roadkill carcasses that are examined using morphological characteristics to determine whether they are 'true' polecats or ferret hybrids (Birks 2008; Croose 2016) or report roadkill to map species recovery (Fig. 3). Over half of polecat records received by Vincent Wildlife Trust were road casualties (Croose 2016), consistent with other distribution surveys (Birks and Kitchener 1999; Birks 2008; Fig. 3), demonstrating the importance of roadkill in recording species recovery.

Invasive species represent taxa for which roadkill data could be informative. Invaders cost billions in economic losses, create large-scale ecological perturbation, and displace native species (Vila et al. 2011; Dorcas et al. 2012). Monitoring their arrival and spread is critical, but expensive (Hauser et al. 2006). The spread, control efficacy, and ecosystem impacts of invasive species can be informed through roadkill at a low cost. As species in the initial stages of invasion are usually at low densities, detection via surveillance can be difficult (Berry et al. 2007), but a roadkill carcass offers undeniable evidence of a species' presence and can trigger an increase in surveillance and control efforts in a given location, as was the case for the early stages of red fox (Vulpes vulpes) invasion in Tasmania (Berry et al. 2007; Caley et al. 2015). The large amount of biomass provided by (native) roadkill could facilitate expansion of invasive species; the non-native, generalist scavenger, pied crow (Corvus albus), in southern Africa was strongly associated with the presence of roadkill (Joseph et al. 2017). Roadkill animals can provide insight into how invasion is progressing, as observed for the established invasive raccoon dog (Nyctereutes procyonoides) in Poland, where almost all $(90 \%)$ of roadkill animals were dispersing juveniles, inferring a healthy breeding population (Kowalczyk et al. 2009). Where an invader is well established, for example the invasive Burmese python (Python molurus bivittatus) in the Everglades National Park, southern Florida (Dorcas et al. 2012), roadkill provides insight into ecosystem impacts as the pythons' main prey item, the raccoon (Procyon lotor), has undergone a $99.3 \%$ reduction in roadkill observations since pythons became established (Dorcas et al. 2012).

\section{Population trends and impacts}

Biodiversity data collated as roadkill can be used to examine both long- and short-term changes in population trends because roadkill numbers can accurately reflect live population densities (Baker et al. 2004; Gehrt 2002; George et al. 2011). The data collated for roadkill can therefore be used to estimate species trends without the need for observations of the live 

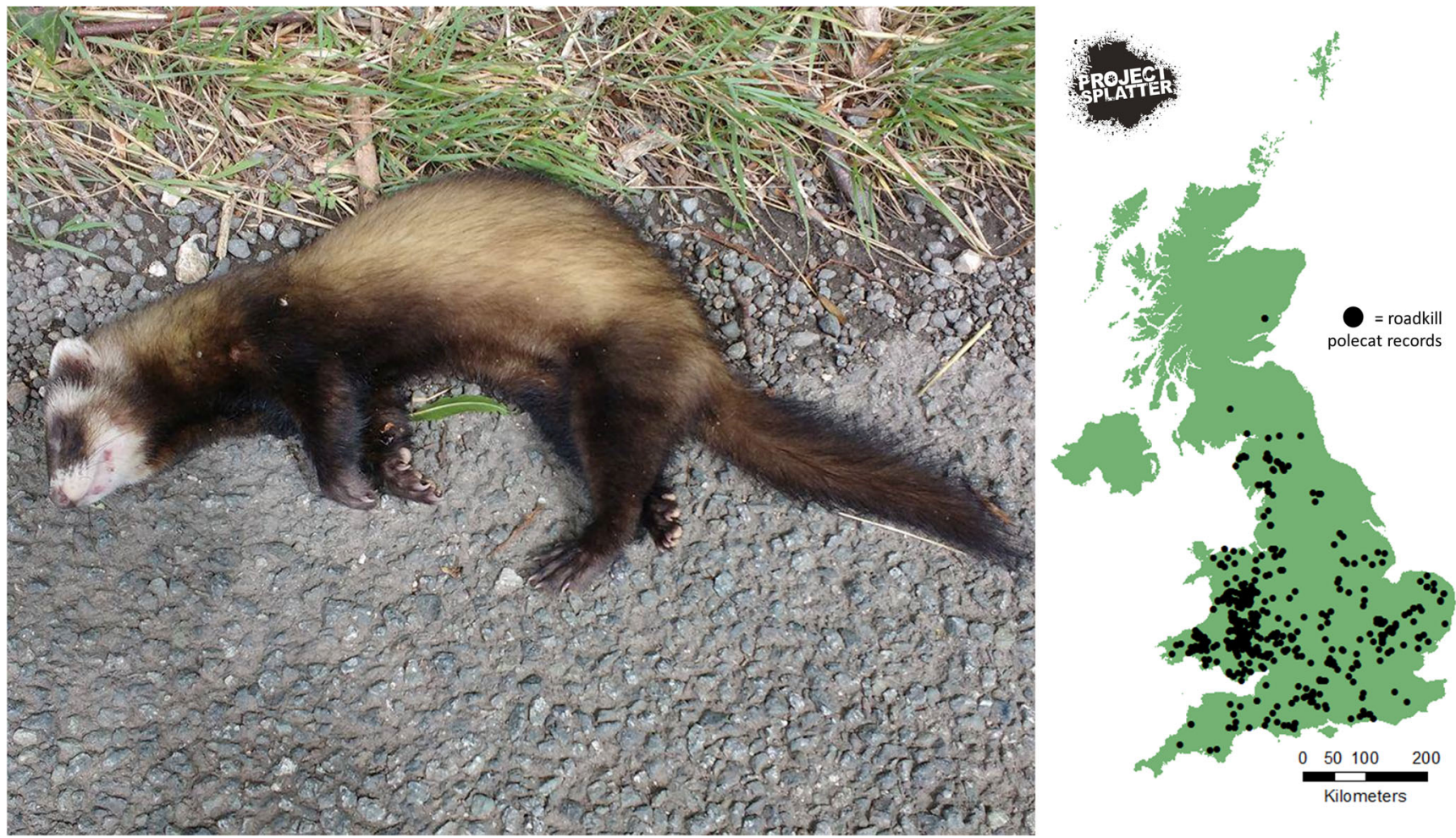

Fig. 3 Roadkill polecat. Physical characteristics of such casualties can be used to determine levels of hybridisation between polecats and feral ferrets, as well as to record their geographical distributions. Inset map shows distribution of polecat roadkill records in the UK as collated by wildlife-vehicle collision citizen science project 'Project Splatter' (photo: Barry Deakin) animals (for example rabbits (Oryctolagus cuniculus, George et al. 2011) and urban foxes (Baker et al. 2004)), or to evaluate spatial differences in population density (e.g. raccoons; Gehrt 2002). The benefit of collating these data in the long term is also apparent; it was roadkill records that revealed the longterm decline in hedgehog (Erinaceus europaeus) numbers in the UK (Pettett et al. 2017; Wembridge et al. 2016).

The greatest known cause of mortality for some species is vehicle collisions. Of a sample of 80 radio-tagged ocelots (Leopardus pardalis) in the USA, collisions with vehicles were the largest single cause of mortality, causing $45 \%$ of deaths (Haines et al. 2012). Similarly, there are an estimated 50,000 badgers (Meles meles) killed on the roads per year in the UK, with vehicle collisions the highest single cause of mortality for this species (Harris et al. 1992). Roads are also the highest single cause of mortality for bobcats (Lynx rufus) in Illinois, USA (Nielsen and Woolf 2002), otters (Lutra lutra) in most European countries (Hauser et al. 2006; Silke et al. 2006), and an important mortality factor for juvenile swift foxes (Vulpes velox) in Kansas, USA (Sovada et al. 1998) and the Florida panther (Puma concolor couguar; McClintock et al. 2015) in Florida, USA.

A meta-analysis of terrestrial vertebrate mortality has shown that, overall, $6.25 \%$ of mortality of adult animals is due to vehicle collisions (Hill et al. 2019). Roadkill data combined with population viability analyses can provide far more insight into the potential impacts of roads on a given species/ population than roadkill counts alone; e.g. for small rodents in Spain, collisions cause a potentially insignificant mortality rate of around 6\% each month (Ruiz-Capillas et al. 2015). Impacts of roads can, however, be significant; populations of Blanding's turtles (Emydoidea blandingii; Beaudry et al. 2008), spotted salamanders (Ambystoma maculatum; Gibbs and Shriver 2005), and jaguars (Panthera onca; Cullen et al. 2016) have been found to be under threat of extinction due to roads.

\section{Why did the animal cross the road? Insights into behaviour}

Wildlife-collision data can reveal broad behavioural patterns; annual peaks of roadkill in spring and late summer (Clarke et al. 1998; Haigh 2012), for example, are indicative of seasonality in mating, dispersal, and foraging behaviours in badgers (Davies et al. 1987) and pheasants (Madden and Perkins 2017). Variations in temporal reporting rates of roadkill of a wide range of other vertebrate species can also be explained by differences in their behaviour and ecology, for example searching for mates, or increased foraging activity at particular times of year (Erritzoe et al. 2003; Clevenger et al. 2003). Similarly, reporting rates of a given species or taxa (e.g. raccoon dogs; Kowalczyk et al. 2009, and other carnivores; Grilo 
et al. 2009) may increase at a time when juvenile dispersal is taking place, due to both an inflated population size and the presence of inexperienced young animals (Erritzoe et al. 2003; Clevenger et al. 2003; Kowalczyk et al. 2009; Grilo et al. 2009; Madden and Perkins 2017). Polecats in the UK, for example, have a bimodal peak in roadkill observations: the spring peak being primarily adult males (mate searching) and the autumn peak mostly juveniles (dispersing) (Birks 2015).

Although animal movement and foraging behaviour can be observed through other means (e.g. GPS tagging), roadkill can reveal changes in a species' behavioural patterns over time, without the need for costly equipment. For example, pheasant (Phasianus colchicus) mortality on UK roads has significantly changed in pattern and increased in numbers from the $1960 \mathrm{~s}$ (prior to mass release of pheasants for shooting at the current scale) to the 2010s, when in excess of 35 million birds are released per year (Madden and Perkins 2017). Pheasants were formerly (during the 1960s) most often reported as vehicle collisions during the breeding season in the spring, but roadkill now also peaks between September and November, when millions of birds are released for the shooting season, which begins in October. The change in temporal patterns is unlikely, in this specific case, to be related to other factors that have changed over time, for example an increase in traffic flow, as the same study found that patterns of woodpigeon (Columba palumbus) roadkill did not significantly differ over the same time period (Madden and Perkins 2017). An added risk factor for captive-bred animals (such as many UK pheasants) is their naivety to roads compared with wild-bred animals (Leif 1994); a pattern was also observed in released Tasmanian devils (Sarcophilus harrisii) over multiple generations of captive breeding (Grueber et al. 2017).

Long-term roadkill data could be particularly useful to observe changes in temporal behaviour due to our current shifting climate. For example, climate change-driven changes in phenological patterns have already been observed through a 20-year dataset of roadkill snakes in the Mediterranean, with roadkill peaks shifting earlier in the year, corresponding with earlier warmer temperatures (Capula et al. 2014). As roads can have long-term effects on wildlife, it is perhaps unsurprising that selection for behaviours that promote survival is occurring. For example, adaption of shorter flight initiation distances on roads with higher speed limits has been observed in birds (Legagneux and Ducatez 2013), and 'road-naïve' (immigrant) Florida scrub jays (Aphelocoma coerulescens) experienced yearly mortality of $50 \%$ in areas with roads, compared with $38 \%$ for 'road-experienced' birds (Mumme et al. 2000), showing the capacity for learning 'safe' behaviour around roads. Similarly, increased nocturnality among mammals is associated with human activity and presence, including roads and traffic (Morrison et al. 2014; Gaynor et al. 2018).

\section{Roadkill as sentinels: contaminants and disease}

Efforts to quantify environmental contaminants include monitoring of watercourses and soils through active sampling (Daughton 2004). These abiotic samples, however, do not necessarily accurately represent contaminants that might be biologically relevant, i.e. those found in wildlife or humans due to bioaccumulation of contaminants in living tissues (van der Oost et al. 2003). Roadkill, instead, offers the opportunity to collect a carcass, which can be used as a 'sentinel' for environmental health and wildlife disease. Roadkill is relatively low cost to sample and is particularly useful in the case of rare and/or protected species where destructive sampling is not possible, or desired. The Eurasian otter, a wide-ranging species at the top of the aquatic food chain, is an excellent sentinel for aquatic systems (Chadwick et al. 2011, 2013; Pountney et al. 2015). A long-term roadkill carcass collection project, the 'Cardiff University Otter Project' (https:/www. cardiff.ac.uk/otter-project), has through post-mortems of collected otters found high levels of flame retardants in otter tissues (Pountney et al. 2015), but also declining levels of lead over time, following tighter environmental regulations (Chadwick et al. 2011). A similar long-term carcass collection project that receives roadkill birds of prey, the 'Predatory Bird Monitoring Scheme' (https://pbms.ceh.ac.uk/), has found contaminants such as organochloride insecticides (Heys et al. 2017), flame retardants (Crosse et al. 2013), and anticoagulant rodenticides (Walker et al. 2008) in raptors, sampling that would not have been possible (due to legislative protection) without the collection of roadkill.

The health of a given species could itself be a study focus; for example, stoats, weasels, and polecats were subjects of the first examination for respiratory diseases in this family (Simpson et al. 2016) _ over half of the carcasses examined were collected from the road. This study also identified the first records of Angiostrongylus vasorum (a parasitic nematode) in small mustelids. Some species are routinely monitored for infectious diseases, such as the collection and testing of roadkill deer carcasses for chronic wasting disease (CWD) in the USA (Arkansas Game and Fish Commission 2018). Deer with CWD are highly susceptible to being struck by a vehicle compared with healthy individuals (Krumm et al. 2005), so although in this scenario roadkill may represent a biased sample in terms of assessing the proportion of the population that is affected, it is, however, particularly useful to map disease spread (Krumm et al. 2005) and prevents the need for destructive sampling outside of the deer hunting season. Indeed, new areas of CWD infection have been identified due to the collection and testing of roadkill (Arkansas Game and Fish Commission 2018). Devil facial tumour disease (DFTD), one of only two transmissible cancers known in wildlife, causes high mortality in Tasmanian devils (Hawkins et al. 2006). Tasmanian devils are also highly vulnerable to collisions with vehicles (Jones 
2000), and collecting and testing of these roadkill devils assist in monitoring the spread of DFTD and have even identified a new strain of the pathogen (Pye et al. 2016).

Bovine tuberculosis (Mycobacterium bovis; bTB) is a disease of significant economic and welfare concern due predominantly to its effects on cattle herds (Independent Scientific Group 2007). For these reasons, the levels of bTB in wildlife are of particular interest, and badgers are an important reservoir (Delahay et al. 2002). Testing roadkill carcasses offers a way of quantifying the levels of bTB in badgers as well as identifying spatial distribution. A dedicated survey in Wales, UK, collected 442 carcasses, of which 25 (7\%) tested positive for bTB (Animal and Plant Health Agency 2016). The largest systemic UK survey of bTB infection in mustelids other than badgers comprised of samples opportunistically collected samples from the South West of England (Delahay et al. 2007), of which over a quarter (27.4\%) were wildlife-vehicle collisions. This work was also the first to confirm stoat (Mustela erminea) and polecat as sylvatic reservoirs for bTB (Delahay et al. 2007).

Considering that over $70 \%$ of parasites and pathogens are zoonotic in origin, i.e. they have wildlife as a primary source (Jones et al. 2008), roadkill offers an excellent opportunity for screening infectious disease risk to humans. Raccoons are a reservoir for Baylisascaris procyonis, a parasite which has the potential to cause severe illness in humans, and of which > $80 \%$ of roadkill raccoon carcasses were found to be infected (Weinstein 2016). Roadkill raccoon carcasses have also been used to monitor the spread of rabies during an outbreak in Baltimore, MD (Anthony et al. 1990). Roadkill samples have provided the first evidence of the zoonotic disease M. avium ssp. paratuberculosis in a diverse range of wild carnivores in Portugal (Matos et al. 2014). Given sufficient and widespread samples, not only can wildlife roadkill be used as sentinels of zoonotic pathogens, but also they can shine light on their spatial distribution. Analysis of otter carcasses, for example, found that Toxoplasma gondii (a zoonotic parasite with the capacity to infect all endothermic vertebrates) was common (39.5\% prevalence, $n=271$ ) and that infection was significantly higher on the east coast of the UK, potentially due to the drier climate leading to increased oocyst survival (Chadwick et al. 2013; Smallbone et al. 2017).

\section{Roadkill monitoring as a tool for citizen science}

So pervasive is wildlife roadkill that one benefit is achieved in the surveying of its presence, so engaging the public as 'citizen scientists': volunteer individuals who collect and/or process data as part of a scientific inquiry (Silvertown 2009). All of the 12 roadkill recording schemes listed on globalroadkill.net engage citizen scientists to collect roadkill data, a process which can be 97\% accurate in its identification of species (Waetjen and Shilling 2017). The rise of smartphones and the popularity of social media platforms have greatly expanded the possibilities for wide-scale environmental data collection, including that of roadkill (Vercayie and Herremans 2015). Although the practice of members of the public voluntarily gathering data for a project is not a new one (the National Audubon Society started its annual Christmas Bird Count in 1900 (Droege 2007)), technology has allowed many new 'citizen science' projects to emerge in recent years, which curate the collective observations of members of the public to record data, whilst being unconstrained by time and geographical locations (Bonney et al. 2009).

Globally, a network of roadkill recording systems exists (Shilling et al. 2015), spanning multiple countries, for example the Austria-based 'Project Roadkill' (https://roadkill.at/ en/) and the 'Wildlife and Roads Project' in South Africa (https://www.ewt.org.za/WTP/road.html). In the UK, Project Splatter (www.projectsplatter.co.uk) is the only UK-wide and year-round project that aims specifically to collect data on all wildlife roadkill. Since the project's inception in 2013, to date, it has received over 70,000 ad hoc records from the public. There are state-specific citizen science roadkill recording projects in the USA, for example the California Roadkill Observation System (http://wildlifecrossing.net/california, UC Davis); Maine Audubon Wildlife Road Watch (http:// www.wildlifecrossing.net/maine, Maine Audubon and UC Davis); and the Idaho Fish and Wildlife Information System (https://idfg.idaho.gov/species/roadkill, Idaho Department of Fish and Game). All projects receive roadkill observations from members of the public, which are submitted through websites, social media, smartphone apps, or a combination of channels (Shilling et al. 2015).

As well as the obvious benefits that a widespread network of volunteers offers, it is important to note that a citizen science project is a two-way interaction between project coordinators and members of the public, such that each group can benefit from interactions with the other (Haklay 2015). Participating in citizen-science wildlife-recording projects has been shown to increase the amount of time that people spend observing wildlife, even after they finish participating (Bonney and Thompson 2007). Most participants (90\%) that took part in a citizen science project named 'Neighbourhood Nestwatch', recording birds in their gardens around Washington DC, reported learning from participating in the project, with even the most experienced birders reporting learning more about bird biology and behaviour (Evans et al. 2005).

\section{Roadkill monitoring and ecology-opportunities for the future}

Roadkill monitoring can inform us about a diverse range of fields; as such the value of collecting these data is to facilitate the expansion of knowledge across a variety of research areas (Fig. 4). Additionally, the use of 'citizen science' projects that record roadkill facilitates the inclusion of members of the public 

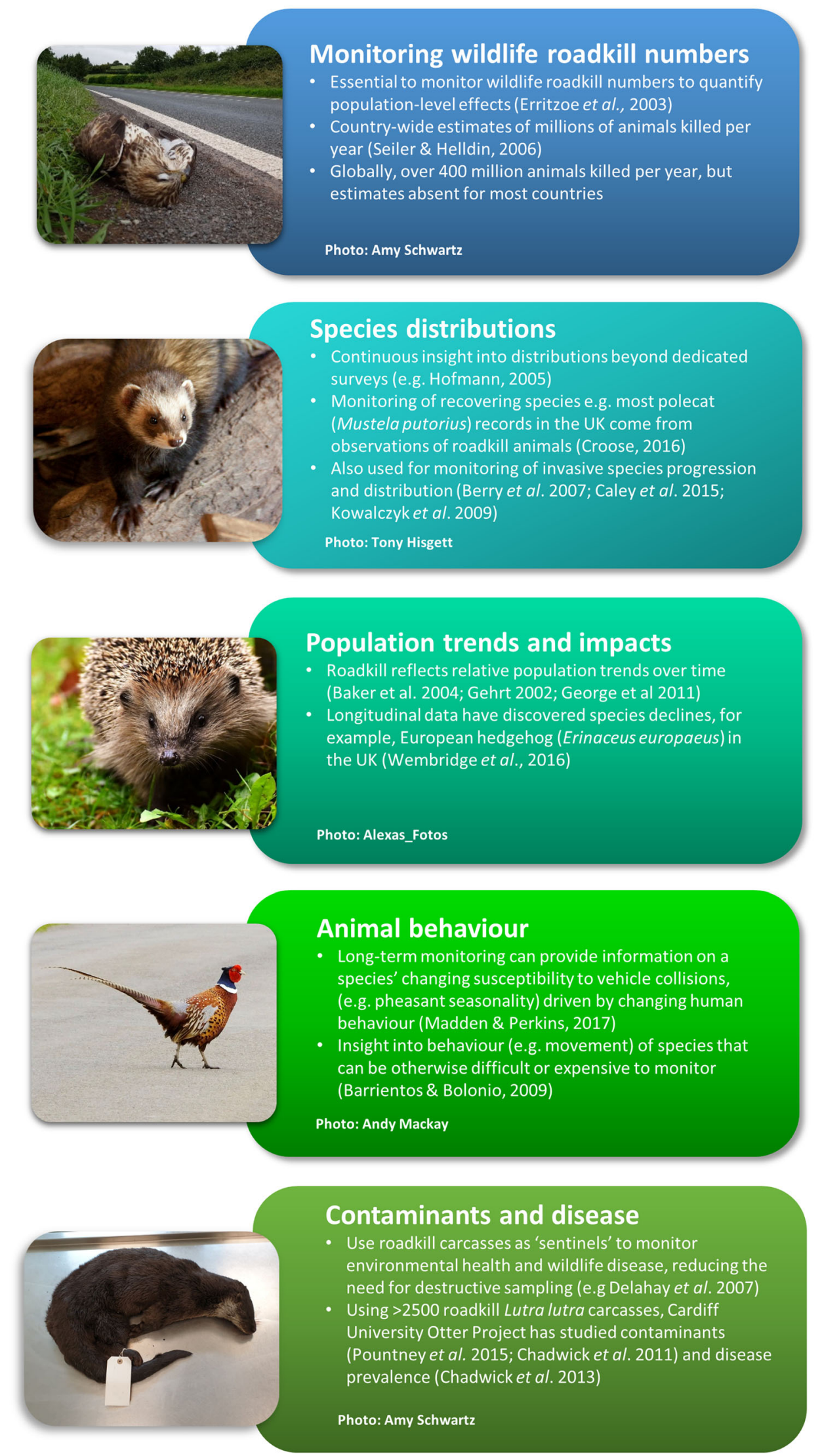

Fig. 4 Infographic outlining the five major areas where consistently, systematically, and extensively monitoring roadkill has facilitated our knowledge of five critical areas of ecological study 
in scientific research (Heigl and Zaller 2016). As roadkill numbers are strongly and positively associated with the local abundance of live animals (Gehrt 2002; Baker et al. 2004; George et al. 2011; Pettett et al. 2017), roadkill monitoring can be used to track long-term changes in population dynamics (Capula et al. 2014). Roadkill records can be used to 'fill in the blanks' on species distribution maps when the live animal is rarely or infrequently seen, as well as for monitoring the spread of species that are both recolonising and invading (Caley et al. 2015; Calenge et al. 2015; Croose 2016), and this species tracking could also include monitoring of changing animal behavioural patterns (Haigh 2012; Madden and Perkins 2017; Sovada et al. 1998). Finally, collecting biological samples from roadkill carcasses can provide increasing ecological and geographic resolution for contaminant studies (Chadwick et al. 2013; Heys et al. 2017; Smallbone et al. 2017).

Although substantial roadkill data is collected globally, there remains a challenge to estimate the extent of the issue; only 13 countries globally have produced country-wide estimates of roadkill, but even these limited estimates amount to over 400 million vertebrates (Fig. 2). Roadkill observation systems can be highly effective in collecting these data (Waetjen and Shilling 2017) for low cost, and more of such projects are needed globally to collect such data, which can then be deposited in global databases (i.e. GBIF). With improvements and standardisation of the metadata associated with roadkill observations, a wide range of ecological studies can be supported. In many ways, roadkill observation is likely to become the most useful single wildlife observation and sampling approach available for ecology.

Acknowledgements The authors wish to thank the member organisations of globalroadkill.net, Dr. David Waetjen (UC Davis), the volunteer contributors of Project Splatter (www.projectsplatter.co.uk), the California Roadkill Observation system (https://www.wildlifecrossing. net/california/), and the Maine Audubon Wildlife Road Watch (https:// www.wildlifecrossing.net/maine/). Finally, we thank Dr. Rafa Barrientos and the three anonymous reviewers, whose comments greatly improved this manuscript.

Funding Information This work was funded by a Knowledge Economy Skills Scholarship (KESS), supported by European Social Funds (ESF) through the Welsh Government. KESS is a pan-Wales higher level skills initiative led by Bangor University on behalf of the HE sector in Wales. It is part funded by the Welsh Government's ESF convergence programme for West Wales and the Valleys. We also thank KESS partner company Eco-Explore (http://www.eco-explore.co.uk/) for contributing to Amy Schwartz's PhD studentship funding.

Open Access This article is licensed under a Creative Commons Attribution 4.0 International License, which permits use, sharing, adaptation, distribution and reproduction in any medium or format, as long as you give appropriate credit to the original author(s) and the source, provide a link to the Creative Commons licence, and indicate if changes were made. The images or other third party material in this article are included in the article's Creative Commons licence, unless indicated otherwise in a credit line to the material. If material is not included in the article's Creative Commons licence and your intended use is not permitted by statutory regulation or exceeds the permitted use, you will need to obtain permission directly from the copyright holder. To view a copy of this licence, visit http://creativecommons.org/licenses/by/4.0/.

\section{References}

Animal \& Plant Health Agency (2016) APHA briefing note 03/16; Badger found dead survey in Wales. http://apha.defra.gov.uk/ official-vets/briefing\%20notes.htm. Accessed 18 Apr 2018

Anthony JA, Childs JE, Glass GE, Korch GW, Ross L, Grigor JK (1990) Land use associations and changes in population indices of urban raccoons during a rabies epizootic. J Wildl Dis 26:170-179. https:// doi.org/10.7589/0090-3558-26.2.170

Arkansas Game \& Fish Commission (2018) Biologists asking motorists to report road-killed deer for disease research. https://www.agfc. com/en/news/2018/02/28/biologists-asking-motorists-to-reportroad-killed-deer-for-disease-research/. Accessed 18 Apr 2018

Ascensão F, Kindel A, Teixeira FZ et al (2019) Beware that the lack of wildlife mortality records can mask a serious impact of linear infrastructures. Glob Ecol Conserv 19:e00661. https://doi.org/10.1016/j. gecco.2019.e00661

August T, Harvey M, Lightfoot P et al (2015) Emerging technologies for biological recording. Biol J Linn Soc 115:731-749. https://doi.org/ 10.1111/bij.12534

Baker PJ, Harris S, Robertson CPJ et al (2004) Is it possible to monitor mammal population changes from counts of road traffic casualties? An analysis using Bristol's red foxes Vulpes vulpes as an example. Mammal Rev 34:115-130. https://doi.org/10.1046/j.0305-1838. 2003.00024.x

Barnes MD (1936) The death-roll of birds on our roads. Nat 1936:85-86

Barrientos R, Martins RC, Ascensão F et al (2018) A review of searcher efficiency and carcass persistence in infrastructure-driven mortality assessment studies. Biol Conserv 222:146-153. https://doi.org/10. 1016/j.biocon.2018.04.014

Beaudry F, deMaynadier PG, Hunter ML (2008) Identifying road mortality threat at multiple spatial scales for semi-aquatic turtles. Biol Conserv 141:2550-2563. https://doi.org/10.1016/j.biocon.2008.07. 016

Berry R (1988) Biological survey - need \& network. PNL Press, London

Berry O, Sarre SD, Farrington L, Aitken N (2007) Faecal DNA detection of invasive species: the case of feral foxes in Tasmania. Wildl Res 34:1-7. https://doi.org/10.1071/WR06082

Birks JDS (2008) The polecat survey of Britain 2004-2006. A report on the polecat's distribution, status and conservation. The Vincent Wildlife Trust, London

Birks J (2015) Polecats. Whittet Books Ltd., Stanstead

Birks JDS, Kitchener AC (1999) The distribution and status of the polecat Mustela putorius in Britain in the 1990s. The Vincent Wildlife Trust, London

Bishop CA, Brogan JM (2013) Estimates of avian mortality attributed to vehicle collisions in Canada. Avian Conserv Ecol 8:2. https://doi. org/10.5751/ACE-00604-080202

Bonney R, Thompson S (2007) Evaluating the impact of participation in an on-line citizen science project: a mixed methods approach. http:// www.archimuse.com/mw2007/papers/thompson/thompson.html. Accessed 22 June 2018

Bonney R, Cooper CB, Dickinson J et al (2009) Citizen science: a developing tool for expanding science knowledge and scientific literacy. BioScience 59:977-984. https://doi.org/10.1525/bio.2009.59.11.9

Calenge C, Chadoeuf J, Giraud C, Huet S, Julliard R, Monestiez P, Piffady J, Pinaud D, Ruette S (2015) The spatial distribution of 
Mustelidae in France. PLoS One 10:e121689. https://doi.org/10. 1371/journal.pone.0121689

Caley P, Ramsey DSL, Barry SC (2015) Inferring the distribution and demography of an invasive species from sighting data: the red fox incursion into Tasmania. PLoS One 10. https://doi.org/10.1371/ journal.pone.0116631

Capula M, Rugiero L, Capizzi D et al (2014) Long-term, climate changerelated shifts in monthly patterns of roadkilled Mediterranean snakes (Hierophis viridifavus). Herpetol J 24:97-102

Chadwick EA, Simpson VR, Nicholls AEL, Slater FM (2011) Lead levels in Eurasian otters decline with time and reveal interactions between sources, prevailing weather, and stream chemistry. Environ Sci Technol 45:1911-1916. https://doi.org/10.1021/es1034602

Chadwick EA, Cable J, Chinchen A, Francis J, Guy E, Kean EF, Paul SC, Perkins SE, Sherrard-Smith E, Wilkinson C, Forman DW (2013) Seroprevalence of Toxoplasma gondii in the Eurasian otter (Lutra lutra) in England and Wales. Parasit Vectors 6:75. https://doi.org/10. 1186/1756-3305-6-75

Clarke GP, White PCL, Harris S (1998) Effects of roads on badger Meles meles populations in south-west England. Biol Conserv 86:117124. https://doi.org/10.1016/S0006-3207(98)00018-4

Clevenger AP, Chruszcz B, Gunson KE (2003) Spatial patterns and factors influencing small vertebrate fauna road-kill aggregations. Biol Conserv 109:15-26. https://doi.org/10.1016/S0006-3207(02) 00127-1

Coffin AW (2007) From roadkill to road ecology: a review of the ecological effects of roads. J Transp Geogr 15:396-406. https://doi.org/ 10.1016/j.jtrangeo.2006.11.006

Costa M, Fernandes C, Birks JDS, Kitchener AC, Santos-Reis M, Bruford MW (2013) The genetic legacy of the 19th-century decline of the British polecat: evidence for extensive introgression from feral ferrets. Mol Ecol 22:5130-5147. https://doi.org/10.1111/mec.12456

Croose E (2016) The distribution and status of polecat (Mustela putorius) in Britain 2014-2015. The Vincent Wildlife Trust, Ledbury, UK

Crosse JD, Shore RF, Jones KC, Pereira MG (2013) Key factors affecting liver PBDE concentrations in sparrowhawks (Accipiter nisus). Environ Pollut 177:171-176. https://doi.org/10.1016/j.envpol. 2013.02.006

Cullen L Jr, Stanton JC, Lima F et al (2016) Implications of fine-grained habitat fragmentation and road mortality for jaguar conservation in the Atlantic Forest, Brazil. PLoS One 11:e0167372. https://doi.org/ 10.1371/journal.pone. 0167372

Daughton CG (2004) Non-regulated water contaminants: emerging research. Environ Impact Assess Rev 24:711-732. https://doi.org/10. 1016/j.eiar.2004.06.003

Davies JM, Roper TJ, Shepherdson DJ (1987) Seasonal distribution of road kills in the European badger (Meles meles). J Zool 211:525529. https://doi.org/10.1111/j.1469-7998.1987.tb01550.x

Davison A, Birks JDS, Griffiths HI, et al (1999) Hybridization and the phylogenetic relationship between polecats and domestic ferrets in Britain. Biol Conserv 87:155-161. https://doi.org/10.1016/S00063207(98)00067-6

Delahay RJ, De Leeuw ANS, Barlow AM et al (2002) The status of Mycobacterium bovis infection in UK wild mammals: a review. Vet J 164:90-105. https://doi.org/10.1053/tvj1.2001.0667

Delahay RJ, Smith GC, Barlow AM et al (2007) Bovine tuberculosis infection in wild mammals in the South-West region of England: a survey of prevalence and a semi-quantitative assessment of the relative risks to cattle. Vet J 173:287-301. https://doi.org/10.1016/j. tvj1.2005.11.011

Department for Transport (2018) Vehicle licensing statistics: quarter 1 (Jan - Mar) 2018. https://assets.publishing.service.gov.uk/ government/uploads/system/uploads/attachment_data/file/729581/ vehicle-licensing-statistics-january-to-march-2018.pdf. Accessed 8 Nov 2018
Dorcas ME, Willson JD, Reed RN, Snow RW, Rochford MR, Miller MA, Meshaka WE Jr, Andreadis PT, Mazzotti FJ, Romagosa CM, Hart KM (2012) Severe mammal declines coincide with proliferation of invasive Burmese pythons in Everglades National Park. Proc Natl Acad Sci 109:2418-2422. https://doi.org/10.1073/pnas. 1115226109

Droege S (2007) Just because you paid them doesn't mean their data are better. In: McEver C, Bonney R, Dickinson J et al (eds) Citizen Science Toolkit Conference. Cornell Laboratory of Ornithology $13-26$

Dyczkowski J (2016) Golden nightjar in western Sahara, Morocco, in May 2015. Dutch Bird 38:80-86

Erickson WP, Johnson GD, Young DP (2005) A summary and comparison of bird mortality from anthropogenic causes with an emphasis on collisions. Tech Rep PSW-GTR-191. US Dept. of Agriculture

Erritzoe J, Mazgajski TD, Rejt $Ł$ (2003) Bird casualties on European roads - a review. Acta Ornithol 38:77-93. https://doi.org/10. 3161/068.038.0204

Evans C, Abrams E, Reitsma R et al (2005) The neighborhood nestwatch program: participant outcomes of a citizen-science ecological research project. Conserv Biol 19:589-594. https://doi.org/10.1111/j. 1523-1739.2005.00s01.x

Forman RTT (1998) Road ecology: a solution for the giant embracing us. Landsc Ecol 13:III-IIV. https://doi.org/10.1023/A:1008036602639

Forman RTT, Alexander LE (1998) Roads and their major ecological effects. Annu Rev Ecol Syst 29:207-231

Gaynor KM, Hojnowski CE, Carter NH, Brashares JS (2018) The influence of human disturbance on wildlife nocturnality. Science 360: $1232-1235$

Gehrt SD (2002) Evaluation of spotlight and road-kill surveys as indicators of local raccoon abundance. Wildl Soc Bull 1973-2006 30:449 456

George L, Macpherson JL, Balmforth Z, Bright PW (2011) Using the dead to monitor the living: can road kill counts detect trends. Appl Ecol Environ Res 9:27-41. https://doi.org/10.15666/aeer/0901 027041

Gibbs JP, Shriver WG (2005) Can road mortality limit populations of pool-breeding amphibians? Wetl Ecol Manag 13:281-289. https:// doi.org/10.1007/s11273-004-7522-9

González-Suárez M, Ferreira FZ, Grilo C (2018) Spatial and species-level predictions of road mortality risk using trait data. Glob Ecol Biogeogr 27:1093-1105. https://doi.org/10.1111/geb.12769

Grilo C, Bissonette JA, Santos-Reis M (2009) Spatial-temporal patterns in Mediterranean carnivore road casualties: consequences for mitigation. Biol Conserv 142:301-313. https://doi.org/10.1016/j. biocon.2008.10.026

Grilo C, Bissonette J, Cramer P (2010) Mitigation measures to reduce impacts on biodiversity. In: Jones SR (ed); Highways: Construction, Management, and Maintenance. Nova Science Publishers, Inc. 73114.

Grueber CE, Reid-Wainscoat EE, Fox S, Belov K, Shier DM, Hogg CJ, Pemberton D (2017) Increasing generations in captivity is associated with increased vulnerability of Tasmanian devils to vehicle strike following release to the wild. Sci Rep 7:2161. https://doi.org/10. 1038/s41598-017-02273-3

Guisan A, Tingley R, Baumgartner JB, Naujokaitis-Lewis I, Sutcliffe PR, Tulloch AI, Regan TJ, Brotons L, McDonald-Madden E, MantykaPringle C, Martin TG, Rhodes JR, Maggini R, Setterfield SA, Elith J, Schwartz MW, Wintle BA, Broennimann O, Austin M, Ferrier S, Kearney MR, Possingham HP, Buckley YM (2013) Predicting species distributions for conservation decisions. Ecol Lett 16:1424 1435. https://doi.org/10.1111/ele.12189

Haigh A (2012) Annual patterns of mammalian mortality on Irish roads. Hystrix-Ital J Mammal 23:57-65. https://doi.org/10.4404/hystrix23.2-4747 
Haines AM, Tewes ME, Laack LL (2012) Survival and sources of mortality in ocelots. J Wildl Manag 69:255-263. https://doi.org/10. 2193/0022-541X(2005)069<0255:SASOMI >2.0.CO;2

Haklay M (2015) Citizen science and policy: a European perspective. The Woodrow Wilson Center. https://www.wilsoncenter.org/sites/ default/files/Citizen_Science_Policy_European_Perspective_ Haklay.pdf. Accessed 9 Nov 2018

Harris S, Cresswell W, Reason P, Cresswell P (1992) An integrated approach to monitoring badger (Meles meles) population changes in Britain. In: McCullough DR, Barrett RH (eds) Wildlife 2001: populations. Elsevier Applied Science, London, pp 945-953

Hauser CE, Pople AR, Possingham HP (2006) Should managed populations be monitored every year? Ecol Appl 16:807-819. https://doi. org/10.1890/1051-0761(2006)016[0807:SMPBME]2.0.CO;2

Hawkins CE, Baars C, Hesterman $\mathrm{H}$ et al (2006) Emerging disease and population decline of an island endemic, the Tasmanian devil Sarcophilus harrisii. Biol Conserv 131:307-324. https://doi.org/10. 1016/j.biocon.2006.04.010

Heigl F, Zaller JG (2016) Factors influencing data quality in citizen science roadkill projects. Front Environ Sci 4. https://doi.org/10.3389/ conf.FENVS.2016.01.00002

Heys KA, Shore RF, Pereira MG, Martin FL (2017) Levels of organochlorine pesticides are associated with amyloid aggregation in apex avian brains. Environ Sci Technol 51:8672-8681. https://doi.org/10. 1021/acs.est. $7 b 00840$

Hill JE, DeVault TL, Belant JL (2019) Cause-specific mortality of the world's terrestrial vertebrates. Glob Ecol Biogeogr 28:680-689. https://doi.org/10.1111/geb.12881

Hodson NL, Snow DW (1965) The road deaths enquiry, 1960-1961. Bird Stud 12:90-99. https://doi.org/10.1080/00063656509476091

Hofmann JE (2005) A survey for the nine-banded armadillo (Dasypus novemcinctus) in Illinois. Center for Biodiversity Technical Report 16. https://www.ideals.illinois.edu/bitstream/handle/2142/10390/ inhsbiodv02005i00016 opt.pdf?sequence $=2$. Accessed 4 May 2018

Hudson N, the Rarities Committee (2009) Report on rare birds in Great Britain in 2008. Br Birds 102:566

Ibisch PL, Hoffmann MT, Kreft S, Pe'er G, Kati V, Biber-Freudenberger L, DellaSala D, Vale MM, Hobson PR, Selva N (2016) A global map of roadless areas and their conservation status. Science 354: 1423-1427. https://doi.org/10.1126/science.aaf7166

Independent Scientific Group (2007) Bovine TB: the scientific evidence. http://www.bovinetb.info/docs/final_report.pdf. Accessed 26 July 2018

Jacobson SL, Bliss-Ketchum LL, de Rivera CE et al (2016) A behaviorbased framework for assessing barrier effects to wildlife from vehicle traffic volume. Ecosphere 74:E01345 7. https://doi.org/10.1002/ ecs 2.1345

Jones ME (2000) Road upgrade, road mortality and remedial measures: impacts on a population of eastern quolls and Tasmanian devils. Wildl Res 27:289-296. https://doi.org/10.1071/wr98069

Jones JPG (2011) Monitoring species abundance and distribution at the landscape scale: monitoring at the landscape scale. J Appl Ecol 48: 9-13. https://doi.org/10.1111/j.1365-2664.2010.01917.x

Jones KE, Patel NG, Levy MA, Storeygard A, Balk D, Gittleman JL, Daszak P (2008) Global trends in emerging infectious diseases. Nature 451:990-993. https://doi.org/10.1038/nature06536

Joseph GS, Seymour CL, Foord SH (2017) The effect of infrastructure on the invasion of a generalist predator: pied crows in southern Africa as a case-study. Biol Conserv 205:11-15. https://doi.org/10.1016/j. biocon.2016.11.026

Kindberg J, Ericsson G, Swenson JE (2009) Monitoring rare or elusive large mammals using effort-corrected voluntary observers. Biol Conserv 142:159-165. https://doi.org/10.1016/j.biocon.2008.10. 009

Kowalczyk R, Zalewski A, Jędrzejewska B et al (2009) Reproduction and mortality of invasive raccoon dogs (Nyctereutes procyonoides) in the Białowieża Primeval Forest (eastern Poland). Ann Zool Fenn 46: 291-301

Krumm CE, Conner MM, Miller MW (2005) Relative vulnerability of chronic wasting disease infected mule deer to vehicle collisions. J Wildl Dis 41:503-511. https://doi.org/10.7589/0090-3558-41.3.503

Langbein J (2007) National Deer-Vehicle Collisions Project England (2003-2005). The Deer Initiative. http://www.deercollisions.co.uk/ web-content/ftp/DVC_England_FinalAs.pdf. Accessed 23 May 2018

Laurance WF, Clements GR, Sloan S, O'Connell CS, Mueller ND, Goosem M, Venter O, Edwards DP, Phalan B, Balmford A, van der Ree R, Arrea IB (2014) A global strategy for road building. Nature 513:229-232. https://doi.org/10.1038/nature13717

Legagneux P, Ducatez S (2013) European birds adjust their flight initiation distance to road speed limits. Biol Lett 9:20130417. https://doi. org/10.1098/rsbl.2013.0417

Leif AP (1994) Survival and reproduction of wild and pen-reared ringnecked pheasant hens. J Wildl Manag 58:501-506. https://doi.org/ $10.2307 / 3809322$

Loss SR, Will T, Marra PP (2014) Estimation of bird-vehicle collision mortality on U.S. roads. J Wildl Manag 78:763-771. https://doi.org/ 10.1002/jwmg.721

Madden JR, Perkins SE (2017) Why did the pheasant cross the road? Long-term road mortality patterns in relation to management changes. R Soc Open Sci 4:170617. https://doi.org/10.1098/rsos.170617

Matos AC, Figueira L, Martins MH, Loureiro F, Pinto ML, Matos M, Coelho AC (2014) Survey of Mycobacterium avium subspecies paratuberculosis in road-killed wild carnivores in Portugal. J Zoo Wildl Med 45:775-781. https://doi.org/10.1638/2014-0010.1

McClintock BT, Onorato DP, Martin J (2015) Endangered Florida panther population size determined from public reports of motor vehicle collision mortalities. J Appl Ecol 52:893-901. https://doi.org/10. 1111/1365-2664.12438

Morrison CD, Boyce MS, Nielsen SE, Bacon MM (2014) Habitat selection of a re-colonized cougar population in response to seasonal fluctuations of human activity. J Wildl Manag 78:1394-1403

Mumme RL, Schoech SJ, Woolfenden GE, Fitzpatrick JW (2000) Life and death in the fast lane: demographic consequences of road mortality in the Florida scrub-jay. Conserv Biol 12:501-512

Nelson G, Ellis S (2018) The history and impact of digitization and digital data mobilization on biodiversity research. Philos Trans R Soc B Biol Sci 374. https://doi.org/10.1098/rstb.2017.0391

Newman C, Buesching CD, Macdonald DW (2003) Validating mammal monitoring methods and assessing the performance of volunteers in wildlife conservation - "Sed quis custodiet ipsos custodies ?" Biol Conserv 113:189-197. https://doi.org/10.1016/S0006-3207(02) 00374-9

Nielsen CK, Woolf A (2002) Survival of unexploited bobcats in southern Illinois. J Wildl Manag 66:833-838. https://doi.org/10.2307/ 3803147

van der Oost R, Beyer J, Vermeulen NPE (2003) Fish bioaccumulation and biomarkers in environmental risk assessment: a review. Environ Toxicol Pharmacol 13:57-149

Pettett CE, Johnson PJ, Moorhouse TP, Macdonald DW (2017) National predictors of hedgehog Erinaceus europaeus distribution and decline in Britain. Mammal Rev 48:1-6. https://doi.org/10.1111/mam. 12107

Pocock MJO, Roy HE, Preston CD, Roy DB (2015) The Biological Records Centre: a pioneer of citizen science. Biol J Linn Soc 115: 475-493. https://doi.org/10.1111/bij.12548

Pountney A, Filby AL, Thomas GO, Simpson VR, Chadwick EA, Stevens JR, Tyler CR (2015) High liver content of polybrominated diphenyl ether (PBDE) in otters (Lutra lutra) from England and Wales. Chemosphere 118:81-86. https://doi.org/10.1016/j. chemosphere.2014.06.051 
Pye RJ, Pemberton D, Tovar C, Tubio JM, Dun KA, Fox S, Darby J, Hayes D, Knowles GW, Kreiss A, Siddle HV, Swift K, Lyons AB, Murchison EP, Woods GM (2016) A second transmissible cancer in Tasmanian devils. Proc Natl Acad Sci 113:374-379. https://doi.org/ 10.1073/pnas.1519691113

Robertson T, Döring M, Guralnick R, Bloom D, Wieczorek J, Braak K, Otegui J, Russell L, Desmet P (2014) The GBIF integrated publishing toolkit: facilitating the efficient publishing of biodiversity data on the internet. PLoS One 9:e102623. https://doi.org/10.1371/ journal.pone. 0102623

Ruiz-Capillas P, Mata C, Malo JE (2015) How many rodents die on the road? Biological and methodological implications from a small mammals' roadkill assessment on a Spanish motorway. Ecol Res 30:417-427. https://doi.org/10.1007/s11284-014-1235-1

Rytwinski T, Soanes K, Jaeger JAG, Fahrig L, Findlay CS, Houlahan J, van der Ree R, van der Grift E (2016) How effective is road mitigation at reducing road-kill? A meta-analysis. PLoS One 11: e0166941. https://doi.org/10.1371/journal.pone.0166941

Safford R, Ash J, Duckworth J et al (1995) A new species of nightjar from Ethiopia. Ibis 137:301-307. https://doi.org/10.1111/j.1474-919X. 1995.tb08025.x

Schwartz ALW, Williams HF, Chadwick E et al (2018) Roadkill scavenging behaviour in an urban environment. J Urban Ecol 4. https://doi. org/10.1093/jue/juy006

Seiler A, Helldin JO (2006) Mortality in wildlife due to transportation. In: Davenport J, Davenport JL (eds) The ecology of transportation: managing mobility for the environment. Springer, Dordrecht 165189

Shilling F, Perkins SE, Collinson W (2015) Wildlife/roadkill observation and reporting systems. In: van der Ree R, Smith DJ, Grilo C (eds) Handbook of road ecology. West Sussex, UK: John Wiley \& Sons, Ltd., 492-501

Silke H, Hermann A, Olaf Z (2006) Mortality patterns of otters (Lutra lutra) from eastern Germany. J Zool 256:361-368. https://doi.org/ $10.1017 / \mathrm{S} 0952836902000390$

Silvertown J (2009) A new dawn for citizen science. Trends Ecol Evol 24: 467-471. https://doi.org/10.1016/j.tree.2009.03.017

Simpson VR, Tomlinson AJ, Stevenson K, McLuckie J, Benavides J, Dagleish MP (2016) A post-mortem study of respiratory disease in small mustelids in south-west England. BMC Vet Res 12:72. https:// doi.org/10.1186/s12917-016-0693-9

Smallbone WA, Chadwick EA, Francis J, Guy E, Perkins SE, SherrardSmith E, Cable J (2017) East-west divide: temperature and land cover drive spatial variation of Toxoplasma gondii infection in Eurasian otters Lutra lutra from England and Wales. Parasitology 144:1433-1440. https://doi.org/10.1017/S0031182017000865

Sovada MA, Roy CG, Bright JB, Gillis JR (1998) Causes and rates of mortality of swift foxes in western Kansas. J Wildl Manag 62:1300 1306. https://doi.org/10.2307/3801994

Vercayie D, Herremans M (2015) Citizen science and smartphones take roadkill monitoring to the next level. Nat Conserv 11:29-40. https:// doi.org/10.3897/natureconservation.11.4439

Vila M, Espinar JL, Hejda M et al (2011) Ecological impacts of invasive alien plants: a meta-analysis of their effects on species, communities and ecosystems. Ecol Lett 14:702-708. https://doi.org/10.1111/j. 1461-0248.2011.01628.x

Vincent Wildlife Trust (2012) Breaking news - pine marten found in Wales - first in 40 years. Vincent Wildlife News. https://www.vwt. org.uk/wp-content/uploads/2015/04/vwt-newsletter-nov-2012.pdf. Accessed 2 May 2018

Waetjen DP, Shilling FM (2017) Large extent volunteer roadkill and wildlife observation systems as sources of reliable data. Front Ecol Evol 5. https://doi.org/10.3389/fevo.2017.00089

Walker LA, Turk A, Long SM et al (2008) Second generation anticoagulant rodenticides in tawny owls (Strix aluco) from Great Britain. Sci Total Environ 392:93-98. https://doi.org/10.1016/j.scitotenv. 2007.10.061

Weinstein SB (2016) Baylisascaris procyonis demography and egg production in a California raccoon population. J Parasitol 102:622-628. https://doi.org/10.1645/15-747

Wembridge DR, Newman MWP et al (2016) An estimate of the annual number of hedgehog (Erinaceus europaeus) road casualties in Great Britain. Mammal Commun 2:8-14

Publisher's note Springer Nature remains neutral with regard to jurisdictional claims in published maps and institutional affiliations. 